\title{
Neurological complications in children with non-neurological malignancies: A single institution experience
}

\author{
Mukesh Mishra ${ }^{1}$, Areesha Alam², Sciddhartha Koonwar ${ }^{1}$, Archana Kumar², Ravindra \\ Garg$^{1}$, and Rashmi Kumar ${ }^{1}$ \\ ${ }^{1}$ King George's Medical University \\ ${ }^{2}$ Era's Lucknow Medical College and Hospital
}

November 19, 2020

\begin{abstract}
Purpose: Central nervous system (CNS) involvement usually confers poor prognosis in cancer. We aimed to estimate prevalence of neurological-complications ( $\mathrm{NC}$ ) in children presenting with non-neurological malignancy and to describe type, aetiology and outcome of such complications Methods: A bidirectional cohort study of children (1 month-15 years) with non-neurological malignancy was conducted at tertiary-care teaching hospital, North India. Prevalence and spectrum of NC was determined. Etiological diagnosis was made using neuroimaging, cerebrospinal-fluid analysis, nerve-conduction velocity, history and clinical examination. Results: A total of 1572 patients (870 with haematological-malignancy; $55.6 \%$ and 702 with solid tumours; $44.4 \%$ ) were enrolled. Most of them presented within 5-10 years of age and were males ( $72 \%)$. Overall frequency of $\mathrm{NC}$ was $10.5 \%$ (Haematological: 9.4\%; solid: 11.8\%). Highest proportion of $\mathrm{NC}$ was seen in RB (17.2\%), followed by Neuroblastoma (16.6\%), acute myeloid-leukaemia (AML) (16.6\%), Ewing's sarcoma (16.1\%) and Langerhans cell histiocytosis (LCH) (14.2\%). Frequent symptoms were seizures $(30.9 \%)$, headache $(18.2 \%)$, bilateral lower-limb weakness $(13.3 \%)$, altered sensorium $(9.7 \%)$, cranial nerve palsy $(9.1 \%)$, loss of vision $(3.0 \%)$, pain in lower-limbs $(1.2 \%)$, aphasia $(0.6 \%)$, ataxia $(0.6 \%)$ and bilateral hearing loss (0.6\%). Common aetiologies of NC included CNS metastasis or intracranial extension (in RB, Rhabdomyosarcoma), spinal metastasis (in Neuroblastoma, Ewing's-sarcoma, germ cell tumour), intracranial bleed (in AML, Hodgkin's-lymphoma, ALL), CNS relapse (ALL), CNS leukaemia (in Non-Hodgkin's-lymphoma), cerebral atrophy (Wilm's-tumor) and Meningo-encephalitis (in LCH). Mortality was high in affected children (80\%). Conclusions: Cancer-specific information about NC may be beneficial for early recognition and judicious management in order to prevent neurological or cognitive morbidity.
\end{abstract}

\section{Hosted file}

PAPER_PBC_CNS_malignancy_final_17112020.pdf available at https://authorea.com/users/ 377020/articles/493849-neurological-complications-in-children-with-non-neurologicalmalignancies-a-single-institution-experience

\section{Hosted file}

Table1.pdf available at https://authorea.com/users/377020/articles/493849-neurologicalcomplications-in-children-with-non-neurological-malignancies-a-single-institutionexperience

\section{Hosted file}

Table2.pdf available at https://authorea.com/users/377020/articles/493849-neurologicalcomplications-in-children-with-non-neurological-malignancies-a-single-institutionexperience 


\section{Hosted file}

Table3.pdf available at https://authorea.com/users/377020/articles/493849-neurologicalcomplications-in-children-with-non-neurological-malignancies-a-single-institutionexperience

\section{Hosted file}

Table4.pdf available at https://authorea.com/users/377020/articles/493849-neurologicalcomplications-in-children-with-non-neurological-malignancies-a-single-institutionexperience

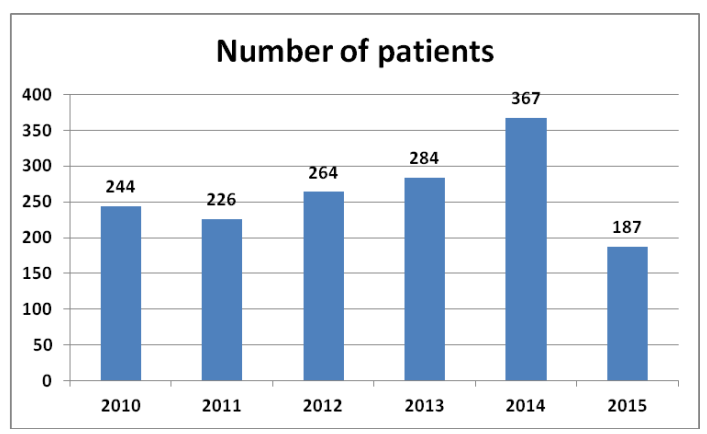

FIGURE 1 Distribution of year wise admissions of non-neurological malignancies 